\title{
Rhetorical Schemes in Barack Obama's Winning Speech
}

\author{
Putu Wahyu Widiatmika*, I Made Budiarsa, I Gde Sadia \\ English Department, Faculty of Arts, Udayana University \\ [wahyuw.9b@gmail.com][made_budiarsa@yahoo.com] \\ [gede.sadia@unud.ac.id] \\ Denpasar, Bali, Indonesia \\ *Corresponding Author
}

\begin{abstract}
This study is aimed to identify the kinds, functions, and meanings of rhetorical schemes applied in Obama's speech. The data of this study were taken by documentation method and note-taking technique from the winning speech delivered by Barack Obama on November, $4^{\text {th }} 2008$ at Grant Park in Chicago. The video is uploaded by Marc Schulz on October, 19th 2012 in YouTube and its transcript is available on $\mathrm{ABC}$ news (internet). In addition, the data were analyzed descriptive qualitatively using Holman's theory about rhetorical devices (1960). This study revealed that there are three schemes in rhetorical devices namely phonological, morphological, and syntactical applied by Barack Obama. Furthermore, two functions applied are to give vivid example and to emphasize points. The meanings from applied rhetorical schemes are constructed based on the reference Obama does in his speech towards socio-historical events in America.
\end{abstract}

\section{Keywords: rhetorical schemes, speech, Obama}

\begin{abstract}
Abstrak
Penelitian ini bertujuan untuk mengidentifikasikan jenis, fungsi, dan makna skema retoris digunakan dalam pidato Barack Obama. Data penelitian ini diambil menggunakan metode dokumentasi dan teknik pencatatan dari pidato kemenangan Barack Obama yang disampaikan tanggal 4 November 2008 di Taman Grant di Chicago. Video penyampaian pidato kemenangannya tersebut diunggah oleh Marc Schulz pada 19 Oktober 2012 di YouTube dan transkripnya tersedia di ABC news (internet). Data dalam studi ini dianalisis secara deskriptif kualitatif menggunakan teori piranti retoris oleh Holman (1960) Studi ini menemukan tiga skema retoris yang digunakan yaitu fonologi, morfologi, dan sintaksis. Selanjutnya, terdapat dua fungsi yang digunakan yaitu memberikan contoh dan menegaskan maksud. Makna dari penggunaan skema retoris dikonstruksi berdasarkan acuan Obama terhadap kejadian sosial-historis di Amerika.
\end{abstract}

Kata kunci: skema retoris, pidato, Obama

\section{INTRODUCTION}

Language is used by people to deliver messages. The meanings that are constructed by the people belongs to pragmatics. Levinson (1983:5) defined pragmatics as the study of language use, that is the study of relation between language and context which is basic to an account of language understanding which involves the making of inferences which will connect what is said to what is mutually assumed or what has been said before. There are many types of social communication and one of them is called rhetoric. It is a communication theory originally developed by Aristotle as a

\begin{tabular}{lll}
\hline Info Article & & \\
\hline Received & $:$ & $27^{\text {th }}$ December 2019 \\
Accepted & $:$ & $28^{\text {th }}$ October 2020 \\
Published & $:$ & $30^{\text {th }}$ November 2020
\end{tabular}


means of challenging a number of prevailing assumptions about what constitutes an effective presentation or simply a means of persuasion. In its most basic form, rhetorical communication occurs whenever one person engages another in an exchange of symbol to accomplish some goals (Hauser, 2002:2).

Doing rhetorical communication means having rhetorical devices within it. Holman (1997: 195) described rhetorical devices as forms of expression that depart from normal word or sentence order or from the common literal meanings of words for the purpose of achieving a special effect. Holman divided rhetorical devices into two main groups which are rhetorical schemes and rhetorical tropes. This study is focused only on rhetorical schemes.

By analyzing rhetorical schemes in Barack Obama's winning speech, it is expected to understand the kinds of rhetorical schemes applied in the speech. Furthermore, the functions and meanings of applied rhetorical schemes were also analyzed. Other researches have discussed about the same topic, however current study has the advantage of analyzing the meanings by recreating the related situation which other studies have not done.

Based on the foregoing introduction, this study aims to identify the kinds, functions, and meanings of rhetorical schemes applied in Barrack Obama's Winning Speech.

\section{MATERIAL AND METHOD}

This study is focused on identifying the kinds of rhetorical schemes that are divided in three sub-groups namely phonological, morphological, and syntactical as well as the functions and meanings. Library research method is used in this study.

The data of the study were taken from Barack Obama's winning speech in 2008. It is a speech that marked the winning of Obama as the 44th president of United States of America. The data sources used in this research were the video by Marc Schulz on October, 19th 2012 It is a primary data with the transcription taken from ABC News.

Documentation method and notetaking technique were used in this study. There were several steps to collecting the data. First, the data were collected by watching the video and reading the script. Second, the relevant data were noted and highlighted. Third, the data were classified based on the kinds of rhetorical schemes.

The data were analyzed qualitatively. Data analysis consists of several steps. Firstly, the data were identified and classified according to the kinds of rhetorical schemes using the theory proposed by Holman entitled theory of rhetorical devices (1960), which are divided into phonological scheme, morphological scheme, and syntactical scheme. Second, the functions of the rhetorical schemes found were determined using the theory by Holman (1960). Then, the meanings were analyzed with the help of context of situation theory by Halliday and Hasan. Lastly, the results were presented descriptively.

\section{THEORETICAL BASIS}

There are two theories used in this study, namely Holman's rhetorical device theory (1960) and context of situation theory by Halliday and Hasan (1985). The grand theory of this study was Holman's rhetorical device theory (1960) that is used to answer all of the research problems mainly kinds and functions of rhetorical devices. In order to provide indepth analysis on the meanings, context of situation theory by Halliday and Hasan (1985) is used as a supporting theory. The reason is because the meanings are built based on the situation Barack Obama referred to in the context of 
certain parts of his speech. Therefore, recreating the situation is needed and context of situation theory could help it.

The topic of the study have been done by students from different universities. Alfaki and Albashir (2015) studied about the kinds and functions of rhetorical devices in their research article entitled An Exploration of the Rhetorical Devices in Leila Aboulela's Novel The Translator which is published on on American International Journal of Contemporary Research Volume 5 Number 1 on February 2015. Munthe and Lestari from English Letters Department Sananta Dharma University also did a research on rhetorical devices entitled The Impression of Rhetorical Devices in Wendy's Tagline (2016) which is published in Journal of Linguistics and Literature Volume 16 Number 2 on October 2016. The research attempts to find out kinds of rhetorical devices used in the taglines of Wendy, a fast-food restaurant, and how the taglines impress the audiences' attentions. The differences between these two articles and current study are the topic which this study is more specific. Furthermore the theory used is different.

As rhetorical schemes are parts of stylistic choice in arranging texts, an article entitled Stylistic Analysis in Janet Dailey's Novel Tangled Vines written by Martini (2014) published Humanis Journal Faculty of Arts Udayana University Volume 7.3 June 2014 is chosen to be reviewed. The article is relevant to be reviewed as stylistic analysis deals with word of use, sentence structure, and pattern of sound device which are the bases of rhetorical schemes. Furthermore, other articles that are reviewed related to this field are Wisam (2015) entitled Stylistic Analysis of the Poem To a Skylark by P.B. Shelley published in Journal Humanities and Social Science, 20(3), 124-137, Hanif et al (2015) entitled A Stylistic Analysis of
William Henry Davies' Leisure published on Journal of Literature, Languages and Linguistics, 7, 30-36, and Shaheen et al (2015) entitled Stylistic Analysis of the Poem The Red Whel Barrow by William Carlos William published on European Journal of English Language and Literature Studies, 3(5), 36-39.

Related to the meaning of the rhetorical schemes, an article from Putri (2016) entitled Retorika dalam Novel Kaze No Uta Wo Kike Karya Haruki Murakami published in Humanis Journal Faculty of Arts Udayana University Volume 16.2 August 2016: 254-26 is reviewed. The difference with the current study is the theory and field in which the article used Japanese rhetorics whereas the current study is English. Furthermore, two more reviewed articles are Otieno (2015) entitled Linguistic Description of the Rhetoric: Barack Obama's Political Speeches, Kazemian (2014) entitled Critical Discourse Analysis of Barack Obama's 2012 Speeches: Views from Systemic Functional Linguistics and Rhetoric.

Moreover, three articles are reviewed in synchronizing how rhetorical schemes are related to persuasion. Articles from Taghinezhad (2015) entitled Persuasive Strategies Used in Obama's Political Speech: A CDA Approach Based on Fairclough's Framework, Alemi (2018) entitled Persuasion in Political Discourse: Barack Obama's Presidential Speeches Against ISIS, and Altikriti (2016) entitled Persuasive Speech Acts in Barack Obama's Inaugural Speeches (2009, 2013) and The Last State of the Union Address (2016) are reviewed.

\section{FINDINGS AND DISCUSSION}

There two parts of analysis in this study. The first analysis of this study discusses about the kinds of rhetorical scheme. Meanwhile, the second analysis 
concerns with the functions and meanings of rhetorical schemes.

\section{Kinds of Rhetorical Schemes}

Holman (1960) defines rhetorical schemes as rhetorical devices that have varied sequences and patterns of words that the ordinary ones. $\mathrm{He}$ divides rhetorical schemes into three subdivisions which are phonological, morphological, and syntactical.

\section{Phonological Scheme}

Phonological schemes are rhetorical devices that are marked by the variation of sound produced by the words in phrases or sentences.

[3-1] "It's the answer told by lines that stretched around schools and churches in numbers this nation has never seen"

Sentence [3-1] is considered as alliteration because of the repeated same consonant sound. The same consonant sound which is repeated can be identified in words of 'numbers', 'nation', and 'never' in which the initial letters as the repetitive sound. As the repeated sound is a consonant, therefore this data belongs to consonantal alliteration.

\section{Morphological Scheme}

Morphological schemes are rhetorical devices that have variations of the words arrangement in sentences. The arrangement of words may repeat the words themselves or use similar words altogether in a phrase or a sentence.

[3-2] "It's the answer that led those who have been told for so long by so many to be cynical, and fearful, and doubtful of what we can achieve to put their hands on the arc of history and bend it once more toward the hope of a better day."

Line [3-2] is categorized as synonym. The three words, 'cynical, and fearful, and doubtful', in the expression are equivalent to each other. They have similar meanings. Based on Oxford Advanced English Learner's Dictionaries, cynical means not believing that something good will happen or that something is important. Fearful means nervous and afraid. Doubtful means uncertain. These three words share equivalent meanings which is an indication of synonym. This emphasizes the expression to describe the unhappy condition that the people felt for long time until it reached the point that they became as the three words had described.

\section{Syntactical Scheme}

Syntactical schemes are rhetorical devices that vary on structure of the sentence which may differ from the common one. The structure may be regarded as a deviation because it does not follow the grammatical structure as usual.

[3-3] "For even as we celebrate tonight, we know the challenges that tomorrow will bring are the greatest of our lifetime - two wars, a planet in peril, the worst financial crisis in a century."

Line [3-3] is categorized as asyndeton. The omission of conjunction at the end of the sentence marks the asyndeton expression. Obama used it to ascend the effect of America's issues from the smallest to the biggest. Here, Obama applied the expression of asyndeton by mentioning the possible upcoming challenges or issues.

\section{Functions and Meanings of Rhetorical Schemes}

Based on Holman (1960), the functions of rhetorical devices are to clarify meaning, to provide vivid example, to emphasize, to stimulate associations and emotions, to give life inanimate objects, to amuse, and to ornament. This study also uses theory of context of situation by Halliday and 
Hasan (1985) in order to recreate the situation to determine the meaning of applied rhetorical devices.

\section{Phonological Scheme}

[5-1] "It's the answer told by lines that stretched around schools and churches in numbers this nation has never seen"

This reflects their hope and expectation to Obama. The people acknowledged that Obama had the right judgment to be a good president because he kept in touch with people. Another factor of why people voted and put their hopes on Obama was their feeling of McCain, as the opposition, was still under Bush's shadow due to both coming from Republican Party. They thought they McCain would do the same and continue the policies Bush had made. However, people did not receive benefits, particularly in economy and healthcare. Therefore, economy was dominant issue on the 2008 election. More than 63\% voters in 2008 proposed that economy as the most important issue facing the country. Obama addressed these issues and got the trust by the society. The data showed that based on economy issue, $53 \%$ voted for Obama, whereas on healthcare, $73 \%$ for him. Due to their sense that McCain might do the same as Bush and people needed new start, Obama won the vote.

Obama used alliteration to create memorable line about the huge amount of answers in history of America. Furthermore, through the expression, he provided a vivid example of the voters. About five million more people voted for president in the 2008 election compared to four years earlier. Data noted that two million more black and Hispanic voters and 600.000 additional Asians voted.

\section{Morphological Scheme}

[5-2] "It's the answer that led those who have been told for so long by so many to be cynical, and fearful, and doubtful of what we can achieve to put their hands on the arc of history and bend it once more toward the hope of a better day."

Obama chose the collection of words to depict what had been going on among Americans. The word 'cynical' resembled the distrust of the people due to the government that could not live up to the citizen's expectation, instead put them in a stagnant or worse situation. The changing or presidency before Obama did not give justice towards the people from all perspectives such as healthcare and economic prosperity. Noted that after the tragedy of $9 / 11$ terrorist attacks in 2001, public trust towards government had declined quickly and in 2007, the percentage of trust the government earned did not surpassed 30\%. Therefore, Obama in his 2008 victory speech chose the word 'cynical' to address those who felt like it, thus he could touch and invoke their emotion and to gain trust from the people.

The word 'fearful' was chosen because previous presidents had fearmongered the people. Fearmonger is the act of spreading fear or alaming news. This action was used attract the voters, particularly in the election. Candidates used the people's fear to win. The more fearful people become, the more gullible they will be. Indirectly, this affected the psychological condition of Americans that they should vote a candidate that could address and overcome their fear. They clung onto their fears and were stressed about how the government solve them. People were afraid if they kept coming back to the same problems without any way out. Fear of terrorism had been one of many fears they have. Since the 9/11 terrorist attacks, people were very concerned about similar cases in the future. Obama 
address those who were fearful in order to reassure them to be brave and believe that he and his team could provide justice and fix the problem.

The word 'doubtful' was picked as the lack of confidence the people had to the government. George Walker Bush as the previous president had promised cutting taxes, aiding minorities, and overcoming poverty. However, during his seven years presidency, the United States of America entered the longest recession. Recession is a decline in economic activity. At the end of his year era, unemployment rose from $4,2 \%$ in 2001 to $7,2 \%$ in 2008 , poverty rate increased from $11,3 \%$ in 2000 to $12,3 \%$ in 2006 , and over 500.000 jobs were lost in November 2008 which marked the largest loss of jobs in the country in 34 years. People had chosen him twice to run as a president, however what they were promised did not happen as Bush campaigned. Therefore, people started to doubt the government's ability to take care of the nation and the subject. Obama then tried to embrace them to trust his presidency.

\section{Syntactical Scheme}

[5-3] "For even as we celebrate tonight, we know the challenges that tomorrow will bring are the greatest of our lifetime - two wars, a planet in peril, the worst financial crisis in a century."

The mentioning of the challenges may refer to certain issues the America had faced or the global issues. Two wars may refer to the Great War which is another name for World War I from 1914 to 1923 and the Civil War from 1861 to 1865 which was a result of a controversy and struggle over enslavement of black people. He also referred to the climate change by saying a planet in peril. Saying a planet in peril is a famous line for saying the environmental effects and changes of the world. What Obama meant by the worst financial crisis in century might also refer to the crisis in 2007 and 2008, the year he won the election. This financial crisis was caused by the United States housing bubble and subprime lending in 2006.

The ascending effect produced by asyndeton expression can also be determined by the period and impact of the issues towards America. He started from the oldest events which were the wars and America had survived and did well. Winning the World War I and ensuring the rights of black people were the proofs. Then, he continued with how the planet started to be in danger environmentally. This particular problem has been happening and controlled way before Obama, but is not only America's issue. United States has been making and applying policies such as British Thermal Unit Tax and Climate Change Action Plan in Bill Clinton's era (1993) and reducing the intensity of greenhouse gasses in 2002 in Bush's era. Lastly, Obama addressing the present issue that is particularly impactful to America. He put it at the end because the issue was just begun and it was his responsibility to solve.

Notice that the use of the asyndeton expression here consists of tricolon. Obama used three series of problems to give powerful impression. Through this line, he wanted to emphasize to the people that no matter what the problem in the future would be, America would still stand strong. He compared the celebration of his victory on the election with the problems and said that the days when America overcome those would still be greater than winning an election.

\section{CONCLUSION}

Based on foregoing, the following points can be drawn as conclusions.

Related to the first problem, the finding showed that Obama used all of the rhetorical schemes: phonological, 
morphological, and syntactical schemes. On phonological scheme, Obama used alliteration. On morphological scheme, he used synonym. Lastly, on syntactical scheme, he applied asyndeton.

Answering the second problem about the function, Obama used the rhetorical schemes to provide vivid example and to emphasize message. He provided example in order to give the illustration the past and future situations. He wanted to give a picture of what America has faced and can be faced. He did it as well to support his previous points. The function to emphasize is used in order to give an in depth description about the condition of America.

Regarding the meaning, the construction of the meaning that Obama tried to convey through the rhetorical schemes is to persuade people. The meanings of the rhetorical devices are mostly about embracing, convincing, and engaging people which prove the theory that rhetorical devices are indeed used to give special effects through languages, one of them is persuasion.

\section{REFERENCES}

ABC News. (2008). FULL TRANSCRIPT: Sen. Barack Obama's Victory Speech [Internet]. Available from: https://abcnews.go.com/Politics/Vo te $2008 /$ story? $\mathrm{id}=6181477$ \&page $=1$ [Accessed on February, 7th 2019]

Alemi, Minoo et al. (2018). Persuasion in Political Discourse: Barak Obama's Presidential Speeches against Isis. Russian Journal of Linguistics. Vol, 22(2) pp 278-291

Alfaki, Ibrahim. (2015). An Exploration of the Rhetorical Devices in Leila Aboulela's Novel The Translator. American International Journal of
Contemporary Research. Vol.5, No.1, February, pp29-38.

Al Shawa, Wisam. (2015). Stylistic Analysis of the Poem "To A Skylark" by P.B. Shelley. Journal of Humanities and Social Science, 20(3), 124-137.

Faust, Drew Gilpin. (2015). Two Wars and The Long Twentieth Century [Internet]. Available from: https://www.newyorker.com/books/ page-turner/two-wars-and-the-longtwentieth-century [Accessed on September, 17th 2019

Halliday, M.A.K., and Ruqaiya Hasan. (1985). Language, Context and Text: Aspect of Language in a Social Semiotic Perspective. Australia, Deakin University, Victoria

Hanif et.al. (2015). A Stylistic Analysis of William Henry Davies' "Leisure". Journal of Literature, Languages and Linguistics. Vol 7, 30-36.

Hauser, Gerard A. (2002). Introduction to Rhetorical Theory. United State of America, Waveland Press, Inc.

Holman, C. Hugh. (1960). A Handbook to Literature. New York, The Odyssey Press.

Holman, C. Hugh. (1997). Figures of Speech: The Encyclopedia Americana International Edition Volume 11. New York, A Grollier Incorporated.

Kazemian, Bahram and Somayyeh Hashemi. (2014). Critical Discourse Analysis of Barack Obama's 2012 Speeches: Views from Systemic Functional Linguistics and 
Rhetoric. Theory and Practice in Language Studies (TLPS). Vol, 4(6), pp 1178-1187

Levinson, Stephen C. (1983). Pragmatics: Cambridge Textbooks in Linguistics. Cambridge, Cambridge University Press.

Linehan, Dave. (2018) Rule of Three Speechwriting [Internet]. Avaiable from: https://davelinehan.com/ruleof-three-speechwriting/ [Accessed on September, $14^{\text {th }} 2019$ ]

Martini, Ni Nyoman. (2104). Stylistic Analysis In Janet Dailey's Novel Tangled Vines. Humanis. Vol, 7(3)

Munthe, Apryanti Madah, and Ria Lestari. (2016). The Impression of Rhetorical Devices in Wendy's Taglines. Journal of Language and Literature. Vol. 16 No. 2

Otieno, Tom Mboya. (2015). Linguistic Description of the Rhetoric: Barack Obama's Political Speeches. IOSR Journal of Humanities and Social Science. Vol, 22(9), pp 80-92

Shaheen et.al. (2015). Stylistic Analysis of the Poem "The Red Whel Barrow" by William Carlos William. European Journal of English Language and Literature Studies, Vol. 3(5), 36-39.

Taghinezhad, Ali and Mehdi Dastpak. (2015). Persuasive Strategies Used in Obama's Political Speech: A CDA Approach Based on Fairclough's Framework. Journal of Applied Linguistics and Language Research. Vol, 2(6), pp 13-27.

Wandari Putri, Putu Zalsa; Rauh Artana, I Nyoman; Widya Purnawati, Ketut. (2016). Retorika Dalam Novel
Kaze No Uta Wo Kike Karya Haruki Murakami. Humanis. Vol, 16(2), pp 254-261 